\title{
Purification and Properties of the Calcium- precipitable Protein in Submaxillary Saliva of Normal and Cystic Fibrosis Subjects
}

\author{
Thomas F. Boa't, ${ }^{[39]}$ Ullrich N. Wiesman, and J. Charles Pallavicini \\ Pediatric Metabolism Branch, National Institute of Arthritis and Metabolic Disease, National Institutes of Health, Bethesda, Maryland \\ and Department of Pediatrics, Case Western Reserve University, Cleveland, Ohio, USA
}

\section{Extract}

A calcium-precipitable protein (CaPP), previously shown to cause turbidity of submaxillary saliva (SMS) in patients with cystic fibrosis (CF), was purified from normal and CF-SMS by $\left(\mathrm{NH}_{4}\right)_{2} \mathrm{SO}_{4}$ precipitation, gel filtration, and preparative polyacrylamide gel electrophoresis. This protein has a molecular weight of 12,000 . It contains large numbers of serine, glycine, and glutamic acid residues, $0.85 \%$ phosphorus as phosphate monoester, and small amounts of carbohydrate. Precipitation (aggregation) of purified $\mathrm{CaPP}$ occurs at basic $\mathrm{pH}$ values in the presence of ionic calcium and is enhanced by increasing calcium concentration, CaPP concentration, or $\mathrm{pH}$. Aggregated $\mathrm{CaPP}$ binds calcium in molar quantities equal to the number of phosphate prosthetic groups. Alkaline phosphatase removes all phosphate from CaPP and eliminates calcium-induced precipitation. Studies of CaPP from CF saliva have demonstrated no electrophoretic or compositional differences from normal CaPP. Higher than normal $\mathrm{pH}$ values or elevated $\mathrm{CaPP}$ concentrations are not present in SMS of patients with CF and do not contribute to the formation of turbid SMS.

\section{Speculation}

Aggregation and precipitation of CaPP in saliva of patients with $\mathrm{CF}$ seems to be induced primarily by elevated levels of calcium in saliva. This precipitation may be entirely, or in part, responsible for focal obstruction of submaxillary gland ducts in patients with GF. However, little or no CaPP is secreted in the lower gastrointestinal or tracheobronchial tracts. Therefore, CaPP does not play a more general role in the obstructive processes which characterize CF.

\section{Introduction}

Turbidity of reflexly stimulated submaxillary saliva (SMS) is a well defined manifestation of CF [4, 10], which can be reversed by intravenous administration of guanethidine [3]. The nature of the solid phase in turbid SMS has not been completely elucidated. Stud- ies by Gugler et al. [10] indicate that turbidity is produced by precipitation of a SMS protein in the presence of elevated concentrations of salivary calcium. Insoluble aggregates are formed by a direct interaction between calcium ions and this protein [2]. Other recent work suggests that inorganic calcium- 
phosphorus complexes are also present in the solid phase of turbid SMS [31]. The relation between these complexes and the calcium-precipitable protein (CaPP) is unclear.

A number of important questions deserve further attention. What sort of protein is Capp? How does it interact with calcium? What additional factors influence the physical state of CaPP? Is CaPP secreted by other exocrine glands? If so, is CaPP aggregation responsible for the obstructive changes which are prominent in the respiratory and gastrointestinal tracts of patients with CF?

In an attempt to answer these questions we have purified CaPP from normal and CF sources, analyzed its structure, studied its interaction with calcium, and determined its distribution in other secretory fluids.

\section{Materials and Methods}

\section{Saliva Collections}

CaPP was purified from a $600-\mathrm{ml}$ pool of stimulated SMS, collected over a 30 - $h$ period from four normal donors, male and female, ages 20-34. Additional samples of CaPP were purified from 30-100 $\mathrm{ml}$ of saliva, collected from six patients with CF (ages 14-26) and six normal subjects (ages 18-30). A modified Schneyer collecting technique [10, 24] and stimulation with sour lemon drops were used for all collections. Two-milliliter samples of unstimulated and stimulated SMS were also serially collected under paraffin oil for $\mathrm{pH}$ determinations.

\section{Chromatographic Procedures}

Gel filtration of 4-ml samples containing 5-15 mg of crude CaPP was carried out on a column $(2.5 \times 75$ $\mathrm{cm}$ ) of Bio-Gel P-10. Samples were eluted by upward flow at a constant rate of $10 \mathrm{ml} / \mathrm{hr}$ with $50 \mathrm{~mm} \mathrm{NaCl}$ containing $10 \mathrm{~mm}$ Tris-HCl (pH 7.05). Protein content of $5.0-\mathrm{ml}$ fractions was monitored by absorbance at 280 nm. Molecular weight determinations by gel filtration were carried out on a column $(2.5 \times 38 \mathrm{~cm})$ of Sephadex G-100 equilibrated with $50 \mathrm{~mm} \mathrm{NaCl}, 10 \mathrm{~mm}$ Tris$\mathrm{HCl}$ ( $\mathrm{pH}$ 7.05), $8 \mathrm{~m}$ urea [7] buffer. Samples for these molecular weight studies were dialyzed against ureacontaining buffer before the application. Three-milliliter fractions were dialyzed against $1 \mathrm{~mm}$ Tris- $\mathrm{HCl}(\mathrm{pH}$ 7.05), lyophilized, and taken up in $3.0 \mathrm{ml}$ of the $\mathrm{NaCl}$, Tris-HCl buffer before absorbance determinations at $280 \mathrm{~nm}$.

\section{Electrophoretic Procedures}

Polyacrylamide gel electrophoresis was carried out at $\mathrm{pH} 8.4$ by the method of Pallavicini and Gugler [21], at $\mathrm{pH} 4.5$ by the method of Reisfeld [23], and at $\mathrm{pH} 7.1$ in sodium dodecyl sulfate (SDS) by the method of Weber and Osborn [30]. Preparative electrophoresis was performed in slabs of $7.5 \%$ polyacrylamide as described previously [21]. Bands were identified in these slabs by superimposing dry cellulose acetate strips on the slab. When completely soaked with buffer, the strips were stained with amido black, dried, and reprositioned on the slab. Appropriate bands were then dissected from the unstained slab and the protein recovered from the gel by electrophoresis into a dialysis bag.

CaPP has no defined unique properties which can be used for quantitation. It cross-reacts immunologically with several other SMS proteins [11], is one of several phosphoproteins in SMS [17], and is not the only calcium-binding protein of SMS, for amylase clearly binds calcium [8]. Therefore, quantitation of CaPP was accomplished by eluting amido black stain from a gel section containing the CaPP band in a known volume of $0.25 \mathrm{M} \mathrm{NaOH}$, then determining the absorbance of the dye solution at $618 \mathrm{~nm}$. The relation between absorbance of eluted dye and the quantity of CaPP applied to acrylamide gels was shown to be linear in separate experiments.

\section{Isoelectric Focusing}

Isoelectric focusing in a $3-6 \mathrm{pH}$ gradient was performed in columns $(5 \times 70 \mathrm{~mm})$ of polyacrylamide gel at $4^{\circ}$ by the method of Wrigley [33]. After focusing, serial 1-mm gel slices were cut and each slice was eluted in $1.0 \mathrm{ml}$ of boiled distilled water for $30 \mathrm{~min}$. The $\mathrm{pH}$ of each eluate was then read with a small combination $\mathrm{pH}$ electrode.

\section{Amino Acid Analysis}

Water-dialyzed CaPP was hydrolyzed for 21, 48, and $68 \mathrm{hr}$ at $110^{\circ}$ with $6 \mathrm{~N} \mathrm{HCl}$ in evacuated, sealed tubes. Aliquots containing $50 \mu \mathrm{g}$ hydrolyzed protein were analyzed on a Beckman model 119 amino acid analyzer.

\section{Frecipitation Studies}

Turbidity of solutions containing aggregated CaPP was assessed by absorbance measurements at $300 \mathrm{~nm}$. A nonturbid CaPP solution containing $0.4 \mathrm{mg}$ per $\mathrm{ml}$ of protein had no absorbance at this wavelength. CaPP 
solutions with and without divalent cation, and containing $1 \mathrm{~mm}$ Tris- $\mathrm{HCl}$ ( $\mathrm{pH} 7.05$ ) to prevent turbidity at low ionic strengths were titrated with $1-\mu l$ aliquots of either $1.0 \mathrm{M} \mathrm{NH}_{4} \mathrm{OH}$ or $1.0 \mathrm{M}$ acetic acid. Each change in $\mathrm{pH}$ was measured with a small combination $\mathrm{pH}$ electrode, followed by an absorbance determination.

\section{Other Procedures}

Calcium was determined on an atomic absorption spectrophotometer (Perkin-Elmer) using lanthanum chloride diluent. Protein determinations were performed by the Lowry procedure [14] using human serum albumin as a standard. Organic phosphorus was determined by the method of Fiske and SubbaRow [9]. Sulfate determinations were performed by a modified benzidine method [1]. Hexoses and fucose were determined by the method of Dische and Shettles [5] and sialic acid by the resorcinol method [27]. Hexosamines were determined with the amino acid analyzer after hydrolysis of samples in $4 \mathrm{~N} \mathrm{HCl}$ for $4 \mathrm{hr}$ at $100^{\circ}$. Amylase activity was assayed by the starch-iodine reaction [28]. Lysozyme activity was measured by the method of Osserman and Lawlor [20] and RNase activity by the method of Kunitz [13].

\section{Results}

\section{Purification of $\mathrm{CaPP}$}

CaPP was initially purified from pooled SMS from normal donors as outlined in Table I. This protein was separated from other SMS proteins by twofold precipitation of pooled SMS with $0.8 \mathrm{M}$, then $0.6 \mathrm{M}$ $(\mathrm{NH})_{2} \mathrm{SO}_{4}$ at $4^{\circ}$. Residual amylase and high molecular weight glycoprotein were removed by Bio-Gel P-10 filtration which excluded these two components and retained CaPP. In the final step, a small quantity of an unidentified protein with a slower anodal electropho- retic migration at $\mathrm{pH} 8.4$ was removed by preparative polyacrylamide gel electrophoresis, yielding a CaPP preparation which was homogeneous by the following criteria.

A single band was demonstrated by polyacrylamide gel electrophoresis of purified CaPP at $\mathrm{pH}$ 8.4, with and without $8 \mathrm{~m}$ urea in the buffer system, and at $\mathrm{pH}$ 7.1 in an SDS system (Fig. 1). No protein migrated toward the cathode on polyacrylamide gel electrophoresis of purified CaPP at pH 4.5. Isoelectric focusing of purified $\mathrm{CaPP}$ in a $\mathrm{pH} 3-6$ gradient produced three closely spaced bands between $\mathrm{pH} 4$ and $\mathrm{pH} 5$. However, after dialysis against $50 \mathrm{~mm}$ EDTA at $\mathrm{pH} 7.0$ for $48 \mathrm{hr}$, CaPP focused as a single sharp band at $\mathrm{pH} 4.4$. The CaPP preparation appeared homogeneous by sedimentation velocity ultracentrifugation (Fig. 2). A single precipitation band was observed when purified CaPP was reacted with rabbit antihuman SMS using a double diffusion microtechnique [29]. No amylase, lysozyme, or RNase enzyme activity was detected in the purified CaPP preparation. This preparation was used for all molecular weight, compositional, precipitation, and calcium-binding studies.

\section{Molecular Weight of CaPP}

A molecular weight of 11,200 was determined from the relative $R_{F}$ values of CaPP and the reference proteins, pepsin, trypsin, myoglobin, lysozyme, cytochrome $c$, and $\alpha$-chymotrypsin [34], all of which had been subjected to electrophoresis simultaneously in SDS-polyacrylamide gels (Fig. 3). Similarly, filtration of CaPP through a Sephadex G-100 column, equilibrated with 8 M urea eluant and calibrated with pepsin, $\alpha$ chymotrypsin, lysozyme, and RNase A, gave a molecular weight of 12,750. An average of the two estimated molecular weights, 12,000, was used for calculation of data subsequently reported in this paper.

Table I. Purification of calcium-precipitable protein (CaPP)

\begin{tabular}{|c|c|c|c|c|c|c|}
\hline Fraction & Volume & $\begin{array}{l}\text { Protein } \\
\text { concentration, } \\
\mathrm{mg} / \mathrm{ml}\end{array}$ & $\begin{array}{c}\text { CaPP } \\
\text { concentration, } \\
\text { units } / \mathrm{ml}^{1}\end{array}$ & Sp Act & Yield, \% & $\begin{array}{c}\text { Fold } \\
\text { purification }\end{array}$ \\
\hline Pooled submaxillary saliva & 600 & 1.20 & 1.06 & 0.88 & 100 & 1.0 \\
\hline$\left(\mathrm{NH}_{4}\right)_{2} \mathrm{SO}_{4}, 0.8 \mathrm{M}$ & 100 & 1.20 & 4.40 & 3.67 & $69^{2}$ & 4.2 \\
\hline$\left(\mathrm{NH}_{4}\right)_{2} \mathrm{SO}_{4}, 0.6 \mathrm{M}$ & 20 & 4.80 & 21.15 & 4.41 & 67 & 5.0 \\
\hline Gel filtration (Bio-Gel P-10) & 10 & 5.24 & 30.00 & 5.71 & 48 & 6.5 \\
\hline Preparative acrylamide gel electrophoresis & 10 & 4.10 & 24.17 & 5.90 & 38 & 6.7 \\
\hline
\end{tabular}

$1 \mathrm{CaPP}$ unit $=$ od at $618 \mathrm{~nm} \times 10^{-1}$ of amido black dye eluted from acrylamide gels as described in the text.

${ }^{2}$ The low yield of CaPP after $0.8 \mathrm{~m}$ precipitation is caused by another SMS protein which migrates at pH 8.4 with the same. $R_{\mathrm{F}}$ as $\mathrm{CaPP}$. This protein is measured as CaPP in the original submaxillary saliva pool, but does not precipitate at $0.8 \mathrm{M}\left(\mathrm{NH}_{4}\right)_{2} \mathrm{SO}_{4}$ concentrations. 


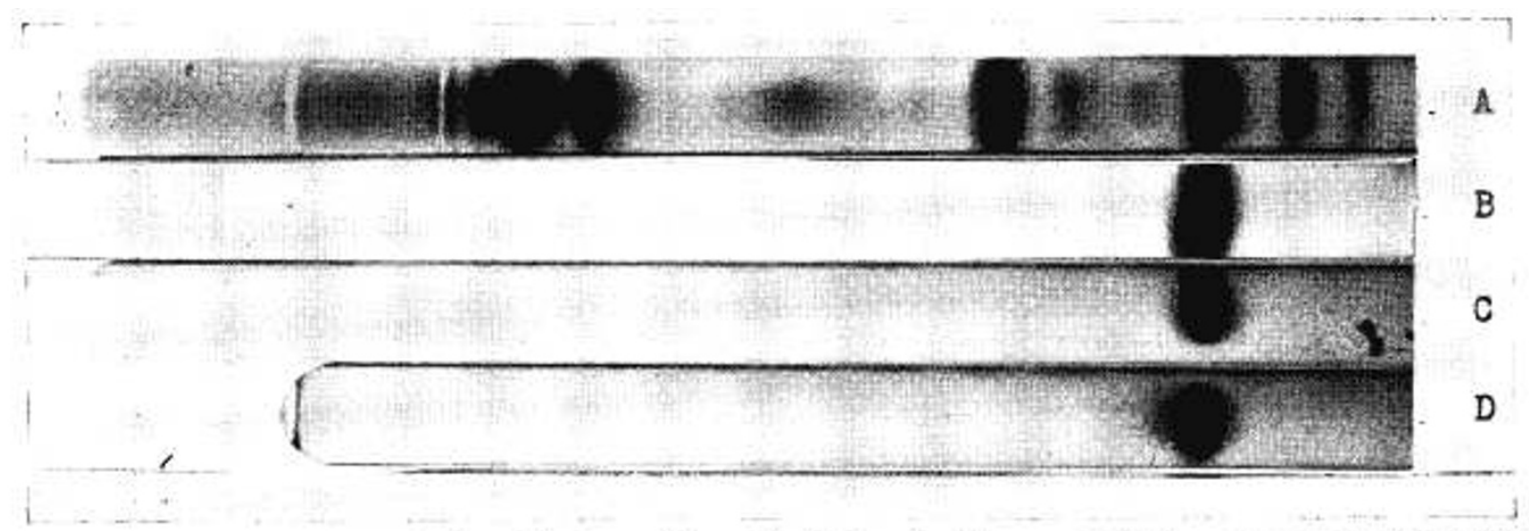

Fig. 1. Polyacrylamide gel electrophoresis of pooled submaxillary saliva $(A)$, and calcium-precipitable protein purified from this saliva pool $(B-D) . B$ : electrophoresis at $\mathrm{pH} 8.4 ; C$ : electrophoresis in $8 \mathrm{~m}$ urea $(\mathrm{pH} 8.4)$; D: electrophoresis in sodium dodecyl sulfate-acrylamide gel (pH 7.1).

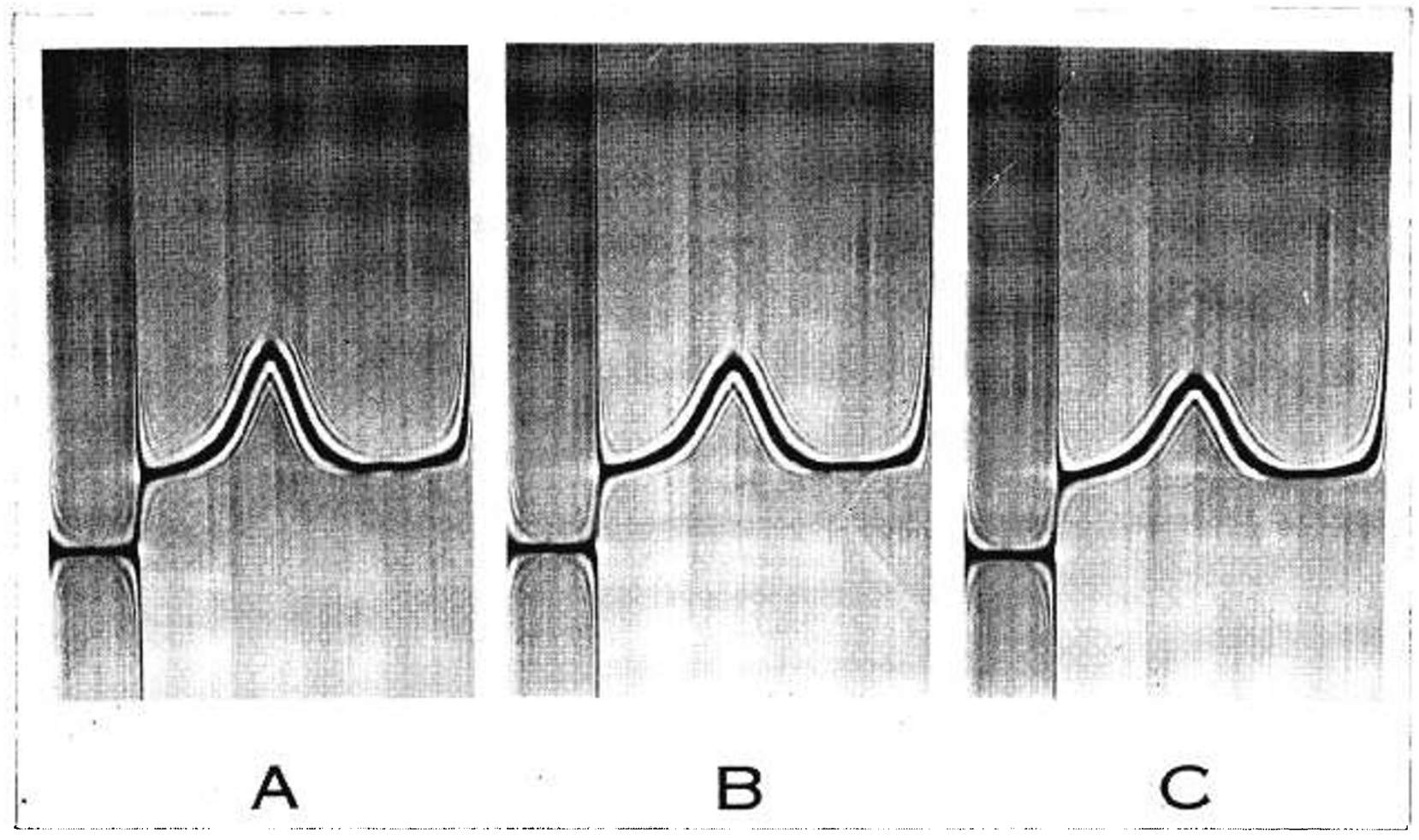

Fig. 2. Schlieren pattern of a sedimentation velocity experiment, using a synthetic boundary cell. Calcium-precipitable protein concentration $=0.5 \%$; temperature $=24^{\circ}$; buffer is $0.1 \mathrm{M} \mathrm{NaCl}, 0.02 \mathrm{M}$ Tris- $\mathrm{HCl}(\mathrm{pH} \mathrm{7.05)}$; exposures at $20(A), 28(B)$, and $36(C)$ min after a speed of $56,000 \mathrm{rpm}$ was reached.

\section{Amino Acid Content of CaPP}

An amino acid analysis of CaPP is reported in $\mathrm{Ta}$ ble II. Serine, glycine, and glutamic acid are the most prevalent amino acids. Ultraviolet spectroscopic analysis [6] of CaPP solutions with and without added $6 \mathrm{M}$ guanidine hydrochloride [35], demonstrated an absence of tryptophan. A minimum molecular weight for CaPP of 12,658 was calculated from these results.

\section{Prosthetic Group Analysis of CaPP}

CaPP contains $5.3 \%$ hexose, but only negligible amounts of fucose, hexosamine, and sialic acid. Of particular interest is the finding of $0.85 \%$ phosphorus, or $3.3 \mathrm{~mol}$ phosphorus/mol CaPP. No sulfate was detected.

Additional information concerning the nature of the phosphorus bound to CaPP is recorded in Table 
III. Inorganic phosphorus can be completely removed from CaPP by incubation with alkaline phosphatase ( $\mathrm{pH} \mathrm{9.0)} \mathrm{or} \mathrm{acid} \mathrm{phosphatase} \mathrm{(} \mathrm{pH} \mathrm{5.8)} \mathrm{for} 4 \mathrm{hr}$, or by incubation with $0.25 \mathrm{~N} \mathrm{NaOH}$ for $15 \mathrm{hr}$. Treatment with $0.25 \mathrm{~N} \mathrm{HCl}$ for $15 \mathrm{hr}$ released no inorganic phos-

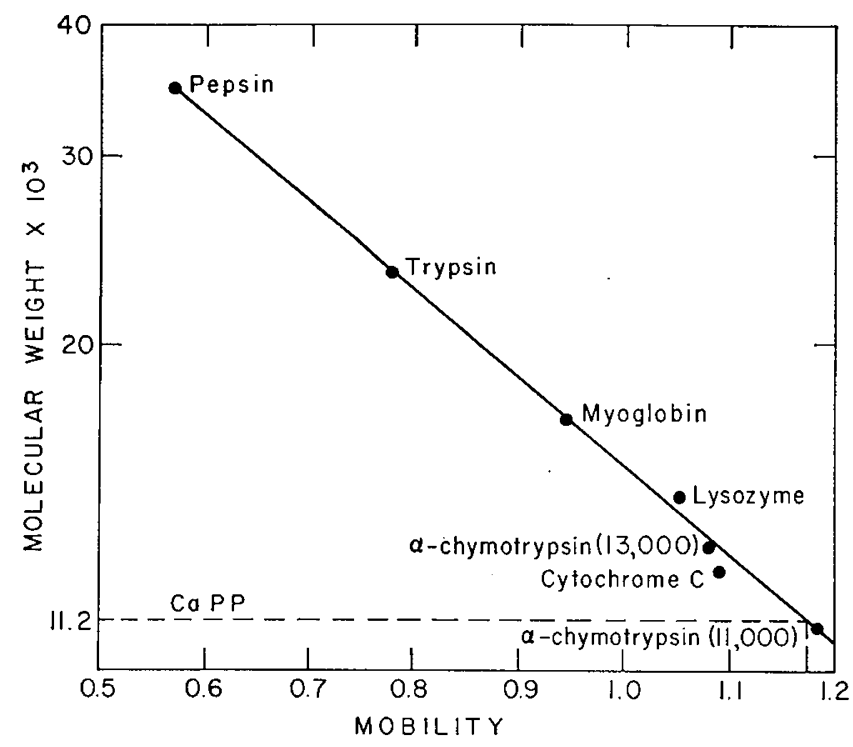

Fig. 3. Molecular weight determination with sodium dodecyl sulfate-acrylamide gel electrophoresis ( $\mathrm{pH}$ 7.I). Mobility of calciumprecipitable protein and reference proteins is compared with that of RNase in the same gel. Relative mobility is plotted against log molecular weight. Calcium-precipitable protein has a relative mobility of 1.17 , giving a molecular weight of 11,200 .

Table II. Amino acid composition of calcium-precipitable protein $^{1}$

\begin{tabular}{lcc}
\hline \multicolumn{1}{c}{ Amino acid } & nmol/g & Residues/mole ${ }^{2}$ \\
\hline Lysine & 0.66 & 8.1 \\
Histidine & 0.08 & 1.0 \\
Arginine & 0.20 & 2.3 \\
Aspartic acid & 0.54 & 6.7 \\
Threonine & 0.36 & 4.4 \\
Serine & 2.20 & 27.5 \\
Glutamic acid & 1.89 & 22.3 \\
Proline & 0.57 & 6.4 \\
Glycine & 1.82 & 22.6 \\
Alanine & 0.66 & 8.3 \\
Valine & 0.28 & 3.1 \\
Isoleucine & 0.17 & 2.1 \\
Leucine & 0.29 & 3.4 \\
Tyrosine & 0.36 & 4.4 \\
Phenylalanine & 0.27 & 3.4 \\
\hline
\end{tabular}

1 Values are averages of 21-, 48-, and 68-hr hydrolysates with the exception of values for threonine and serine which were extrapolated to zero time.

${ }^{2}$ Calculations are based on the assumption that calcium-precipitable protein contains 1 histidine residue.
Table III. Dephosphorylation of calcium-precipitable protein (CaPP)

\begin{tabular}{|c|c|c|c|c|}
\hline Treatment & $\underset{\mathrm{hr}}{\text { Time, }}$ & $\begin{array}{c}\text { Tempera- } \\
\text { ture, } \\
{ }^{\circ} \mathrm{C}\end{array}$ & $\begin{array}{l}\text { Inorganic } \\
\text { phosphorus } \\
\text { released, } \\
\mu g / \mathrm{mg} \mathrm{CaPP}\end{array}$ & $\begin{array}{l}\text { Phos- } \\
\text { phorus/ } \\
\text { CaPP, } \\
\text { mol/mol }\end{array}$ \\
\hline None & 4 & 37 & 0 & 0 \\
\hline Ashed & & & 8.5 & 3.3 \\
\hline $\begin{array}{l}\text { Alkaline phosphatase, }{ }^{2} 1 \\
\text { unit/2 mg CaPP, pH } 9.0\end{array}$ & 4 & 37 & 8.5 & 3.3 \\
\hline $\begin{array}{l}\text { Acid phosphatase, }{ }^{2} \mathrm{l} \text { unit/2 } \\
\text { mg CaPP, pH } 5.8\end{array}$ & 4 & 37 & 7.8 & 3.0 \\
\hline $\mathrm{NaOH}, 0.250 \mathrm{~N}^{3}$ & 15 & 25 & 8.4 & 3.3 \\
\hline $\mathrm{HCl}, 0.250 \mathrm{~N}$ & 15 & 25 & 0 & 0 \\
\hline
\end{tabular}

${ }^{1} \mathrm{CaPP}, 0.4 \mathrm{mg}$, used for each assay.

${ }^{2}$ Boiled enzyme blanks were run at acid and alkaline $\mathrm{pH}$ values.

${ }^{3}$ Removal of phosphorus with $0.250 \mathrm{~N} \mathrm{NaOH}$ was complete only at $15 \mathrm{hr}$.

phorus. These findings indicate that phosphorus is bound to $\mathrm{CaPP}$ as a phosphate monoester [22].

\section{Precipitation of CaPP}

Purified CaPP is only sparingly soluble in distilled water. In $1 \mathrm{~mm}$ buffer or salt solutions which contain no divalent cation, insolubility is observed only in the acidic $\mathrm{pH}$ range. The $\mathrm{pH}$ of maximum insolubility for $\mathrm{CaPP}$ in water or dilute buffer is 4.4 . This $\mathrm{pH}$ value corresponds to the isoelectric point determined by isoelectric focusing.

In the presence of $\mathrm{CaCl}_{2}$, purified CaPP also precipitates at $\mathrm{pH}$ values above 7.0. The effect of calcium concentration, CaPP concentration, and $\mathrm{pH}$ on precipitation of this protein at basic $\mathrm{pH}$ values is illustrated in Figure 4. It is apparent from this graph that an increase of CaPP concentration, calcium concentration, or $\mathrm{pH}$ favors the precipitation of CaPP. Substitution of strontium and magnesium for calcium ions also led to precipitation of CaPP, but only at higher concentrations of the divalent cation or at higher $\mathrm{pH}$ values. Precipitate formed by the interaction of CaPP and calcium was readily dissolved by decreasing the $\mathrm{pH}$ to a $6.0-7.0$ range, or by the addition of small amounts of EDTA. Precipitation of alkaline phosphatase-treated CaPP $(0.5 \mathrm{mg} / \mathrm{ml})$ could not be induced by addition of large amounts of calcium chloride at all $\mathrm{pH}$ values above 7.0 .

\section{Calcium Binding by CaPP}

When $4 \mathrm{mEq} /$ liter calcium was added to $0.5 \mathrm{ml}$ of a $4.0 \mathrm{mg} / \mathrm{ml} \mathrm{CaPP}$ solution at $\mathrm{pH} 7.8,67 \%$ of the CaPP and $38 \%$ of the added calcium was recovered in the 


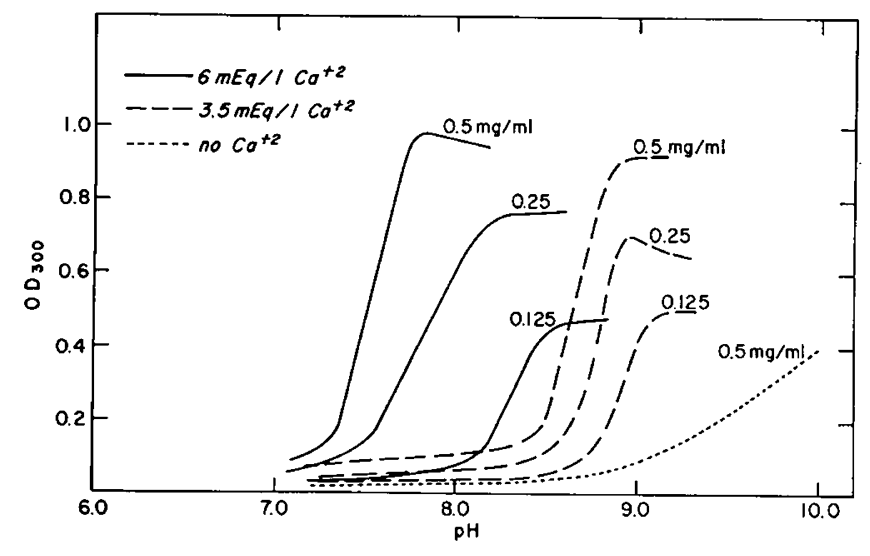

Fig. 4. Turbidity of calcium-precipitable protein solutions as a function of protein concentrations, calcium concentrations, and pH. Concentration of purified calcium-precipitable protein is indicated above each curve. All calcium-containing solutions became visibly turbid during titration. The solution without calcium remained grossly clear despite elevated absorbance at $\mathrm{pH}$ 10.0

washed precipitate. Under these conditions each mole of precipitated protein bound $3.4 \mathrm{~mol}$ calcium.

\section{Binding of CaPP to Hydroxylapatite}

Purified CaPP was adsorbed to a column $(1 \times 10$ $\mathrm{cm}$ ) of hydroxylapatite which had been equilibrated with $0.001 \mathrm{M}$ potassium phosphate $(\mathrm{pH}$ 6.8). Subsequently, no CaPP could be washed from the column by stepwise elution with concentrations of potassium phosphate up to a $1.0 \mathrm{~m}$ concentration.

\section{Comparison of CaPP from Normal (N-CaPP) and CF (CF-CaPP) Sources}

CaPP was also purified from individual submaxillary secretions of six normal subjects and six patients with CF. Turbidity of SMS from CF patients was first. cleared by dialysis of the saliva against $10 \mathrm{~mm}$ EDTA.

Coelectrophoresis of purified CaPP from a normai and a CF source showed identical electrophoretic migration in polyacrylamide gels at $\mathrm{pH}$ 8.4. Similarly, isoelectric focusing of a mixture of EDTA-treated N-CaPP and CF-CaPP in a $\mathrm{pH} 3-6$ gradient produced one sharp band at $\mathrm{pH}$ 4.4. A molecular weight of 12,500 was determined for CF-CaPP by chromatographic analysis on the same column of Sephadex G-100 used for molecular weight determination of N-CaPP. No substantial difference of amino acid composition was found in the $6 \mathrm{~N} \mathrm{HCl}$ hydrolysis product of CaPP from one $\mathrm{CF}$ donor. Six N-CaPP preparations contained $0.85 \pm$ $0.10 \%$ phosphorus, whereas six samples of CF-CaPP contained $0.82 \pm 0.12 \%$ phosphorus. As in the case of N-GaPP, the phosphorus bound to CF-CaPP could be completely removed by incubation with acid and alkaline phosphatase, or with $0.25 \mathrm{~N} \mathrm{NaOH}$. Calcium precipitability of $\mathrm{CF}$-CaPP was also lost after alkaline phosphatase treatment. CF-CaPP from one donor contained $4.6 \%$ hexose and negligible amounts of fucose, hexosamine, and sialic acid. Precipitation of CF-CaPP occurred at alkaline $\mathrm{pH}$ values in the presence of ionic calcium, but the precipitation curves for N-CaPP (Fig. 4) could not be reproduced using either CF-CaPP or N-CaPP which had been precipitated previously with calcium, dissolved with $10 \mathrm{mM}$ EDTA, and dialyzed against dilute Tris-HCl $(\mathrm{pH} 7.05)$ buffer to remove EDTA.

\section{SMS pH in CF and Normal Subjects}

The observed effect of $\mathrm{pH}$ on precipitation of CaPP prompted a comparison of $\mathrm{pH}$ in SMS of six CF subjects and six normal subjects (Table IV). At low flow rates, the mean $\mathrm{pH}$ of SMS from both groups was usually less than 7.0 and no significant difference was found. The mean SMS pH after stimulation increased to values greater than 7.0 in both groups, but a significantly higher $\mathrm{pH}$ was attained in SMS from control subjects $(P<0.01)$.

\section{CaPP Concentration in SMS of CF and Normal Sub- jects}

The observed effect of CaPP concentration on CaPP aggregation likewise prompted a comparison of CaPP concentrations in SMS of CF and normal subjects. The quantity of CaPP recovered during the purification procedure from known volumes of stimulated SMS, pro-

Table $I V . \mathrm{pH}$ of submaxillary saliva from cystic fibrosis (CF) and control subjects

\begin{tabular}{|c|c|c|c|c|}
\hline & \multicolumn{2}{|c|}{ Unstimulated secretions } & \multicolumn{2}{|c|}{ Maximally stimulated secretions } \\
\hline & $\mathrm{pH}$ & Flow rate, $\mathrm{ml} / \mathrm{min}$ & $\mathrm{pH}$ & Flow rate, $\mathrm{ml} / \mathrm{min}$ \\
\hline Normal & $6.57 \pm 0.43$ & $0.18 \pm 0.13$ & $7.65 \pm 0.10$ & $1.64 \pm 1.04$ \\
\hline $\mathrm{CF}$ & $6.75 \pm 0.22$ & $0.21 \pm 0.14$ & $7.40 \pm 0.11$ & $1.95 \pm 1.11$ \\
\hline$P$ value & 0.1 & & $<0.01$ & \\
\hline
\end{tabular}


duced by six normal and six CF donors, was used to estimate original CaPP concentrations. Normal SMS contained $0.15 \pm 0.14 \mathrm{mg} / \mathrm{mI} \mathrm{CaPP}$ and EDTA-treated SMS from CF patients contained $0.09 \pm 0.05 \mathrm{mg} / \mathrm{ml}$ CaPP. No statistical difference was found.

\section{Distribution of CaPP in Other Exocrine Secretions}

Other exocrine secretions were surveyed for the presence of a protein with the same electrophoretic mobility in polyacrylamide gels ( $\mathrm{pH}$ 8.4) as CaPP. Reflexly stimulated parotid saliva, collected with a Lashley cup from both normal and CF subjects, was found to contain a protein with an identical electrophoretic mobility. This protein further resembled CaPP in that it formed a white precipitate within the polyacrylamide gel after immersion of the gel in $60 \mathrm{~mm} \mathrm{CaCl}_{2}$ [10]. A similar protein band could not be demonstrated in duodenal aspirates from three normal and three CF fasting young adult subjects, or from tracheobronchial secretions of three tracheotomized control subjects with neuromuscular disease and two CF patients who had been bronchoscoped.

\section{Discussion}

CaPP, which interacts with ionic calcium to form large aggregates [2] and create turbidity in SMS of patients with $\mathrm{CF}[10]$, is a low molecular weight phosphoprotein containing small amounts of carbohydrate. These studies indicate that phosphorus is covalently bound to CaPP as three or four phosphate monoesters [22], but additional studies are required to establish firmly the nature of phosphate linkages. These studies further indicate that calcium interacts directly with phosphate prosthetic groups of CaPP in a $1 / 1$ molar ratio to effect precipitation.

CaPP differs in several respects from other previously described human secretory proteins. For example, $\alpha$-casein and $\beta$-casein can also be precipitated with calcium but they contain $1.0 \%$ and $0.6 \%$ phosphorus, respectively. The caseins also are larger proteins [19]. Although by definition a glycoprotein, CaPP is very different from the epithelial mucins, which have a very high molecular weight, contain many carbohydrate side chains composed of hexosamine, sialic acid, and fucose, as well as galactose (hexose) residues, and give the mucus secretions their characteristic viscous properties [26].

The mechanism of interaction between this small phosphoprotein and calcium is, as yet, not completely understood. Previous investigators $[4,10]$ have sug- gested that CaPP aggregates when divalent cation bridges are formed between adjacent CaPP molecules. However, we favor an alternate hypothesis, namely, that calcium binding neutralizes the electrostatic charges of phosphate sites, thereby reducing repulsive forces between adjacent molecules and allowing aggregation due to hydrophobic bonding. Neutralization of electrostatic charges at the phosphate sites may also induce conformational changes of the peptide core, exposing additional hydrophobic surfaces for intermolecular binding [2]. A similar mechanism has been proposed for calcium-induced precipitation of $\beta$-casein [19].

The precise conditions required for aggregation of CaPP have not been previously ascertained. Gugler et al. [10] demonstrated that CaPP, present as a band within the matrix of acrylamide gels, will aggregate after immersion of the gel in $60 \mathrm{mEq} /$ liter calcium [10]. The present study further demonstrates that not only CaPP and calcium ions, but also the proper $\mathrm{pH}$, are required for aggregation. Figure 4 illustrates that a calcium concentration within the normal range for SMS (3.5 mEq/liter) [10], purified CaPP will not precipitate unless the $\mathrm{pH}$ exceeds the physiologic range, i.e., is higher than 8.0. On the other hand, at a calcium concentration within the usual range for CF-SMS $(6.0$ $\mathrm{mEq} /$ liter) $[10]$, precipitation will occur in the physiologic $\mathrm{pH}$ range if sufficient CaPP is present. Because $\mathrm{pH}$ and CaPP concentrations are not higher in CF than in normal SMS, it appears that an elevation of the calcium concentration in CF-SMS is the major factor contributing to aggregation of this protein and formation of turbid SMS in patients with CF.

Peptide mapping, and perhaps also amino acid sequence studies, are required to completely rule out structural alteration of CF-CaPP leading to precipitation of this protein. However, molecular weight, electrophoretic, isoelectric focusing, and compositional studies of CaPP from the two sources have failed to uncover a substantial alteration of CF-CaPP.

Other observations confirm the in vivo interaction of calcium, $\mathrm{CaPP}$, and $\mathrm{pH}$ to create $\mathrm{CaPP}$ aggregates and turbid SMS. SMS of patients with CF can be cleared by addition of EDTA which lowers the calcium ion concentration, and normal stimulated saliva can be rendered turbid by addition of calcium ions [10]. Precipitation does not often occur in unstimulated SMS of patients with CF, because the $\mathrm{pH}$ of this secretion is usually below 7.0 , and perhaps also because protein concentrations [25], but not calcium concentrations [15], are significantly decreased at low flow 
rates of saliva. Conversely, we have studied two normal subjects who, after maximal stimulation, produced turbid SMS. These normal subjects secreted SMS containing large amounts of CaPP $(>0.5 \mathrm{mg} / \mathrm{ml})$, but normal calcium concentrations and $\mathrm{pH}$. Failure of CaPP to cause turbidity in parotid saliva of CF or control subjects can be explained by lower concentrations of calcium in this secretion [16]. Guanethidine significantly reduces nitrogen, and presumably total protein, concentrations in SMS of patients with CF [3], and perhaps for this reason prevents CaPP aggregation and turbidity.

Although the present study clearly demonstrates that aggregation of CaPP can proceed in the absence of inorganic phosphate, an additional interaction of CaPP with insoluble calcium-phosphate complexes [31] cannot be excluded. Additional studies will hopefully clarify the role, if any, of inorganic phosphate in CaPP aggregation.

Aggregation and precipitation of CaPP may contribute to the obstruction of submaxillary gland ducts which has been described in patients with CF [7]. However, because CaPP is absent in pulmonary and duodenal secretions, the hypothesis that precipitation of the CaPP results in generalized obstruction of body passageways in patients with CF [10] is no longer tenable. Other calcium-macromolecule interactions, as yet, have not been excluded as pathogenetic factors in $\mathrm{CF}$.

A strong interaction between CaPP and hydroxylapatite suggests that this protein may normally bind to the enamel of tooth surfaces. Indeed, a protein with electrophoretic migration identical to that displayed by CaPP is found in tooth scrapings solubilized with EDTA [12]. In view of the acid resistance afforded enamel by dried salivary films [18], it is intriguing to speculate that CaPP acts specifically to protect tooth surfaces. If so, precipitation of CaPP in the saliva may prevent interaction with enamel surfaces and predispose patients with $\mathrm{CF}$ to more dental caries. Controlled studies are needed to establish the relative incidence of dental caries in patients with CF. The relationship between CaPP, elevated levels of calcium and phosphorus in SMS, and frequent calculus formation in patients with GF [32] also deserves further study.

\section{Summary}

A low molecular weight phosphoprotein, purified from human submaxillary saliva, can be precipitated in vitro by ionic calcium at basic $\mathrm{pH}$ values. Conditions required for precipitation in vitro parallel those conditions which prevail in stimulated submaxillary saliva of patients with $\mathrm{CF}$ and which result in turbidity of this secretion. No alteration of saliva $\mathrm{pH}, \mathrm{CaPP}$ concentration or CaPP structure could be found in submaxillary saliva of patients with CF to explain precipitation of this protein. Increased amounts of calcium in CF submaxillary saliva appear to be primarily responsible for precipitation of CaPP. CaPP is secreted by salivary but not intestinal or tracheobronchial glands. Precipitation of this protein, therefore, does not cause the major obstructive manifestations of CF.

\section{References and Notes}

1. Antonopoulos, C. A.: A modification for the determination of sulfate in mucopolysaccharides by the benzidine method. Acta Chem. Scand., 16: 1521 (1962).

2. Betrelherm, F. A.: On the aggregation of a calcium precipitable glycoprotein from human submaxillary saliva. Biochim. Biophys. Acta, 236: 702 (1971).

3. Chernick, W. S., And Barbero, G. $J .:$ Reversal of submaxillary salivary alterations in cystic fibrosis by guanethidine. Mod. Prob. Pediat., 10: 125 (1967).

4. Chernick, W. S., Barbero, G. J., and Parkins, F. M.: Studies on submaxillary saliva in cystic fibrosis. J. Pediat., 59: 890 (1961).

5. Dische, A., And Shettles, L. B.: A specific color reaction of methylpentoses and a spectrophotometric micromethod for their determination. J. Biol. Chem., 175: 595 (1948).

6. ЕDеLносн, H.: Spectroscopic determination of tryptophan and tyrosine in proteins. Biochemistry, 6: 1948 (1967).

7. FARBer, S.: Pancreatic function and disease in early life. Arch. Pathol., 37: 238 (1944).

8. Fischer, E. H., and Stein, E. A.: $\alpha$-Amylases. In: P. Boyer, H. Lardy, and K. Myrback: The Enzymes, Ed. 2, Vol. 4, p. 343 (Academic Press, New York, 1960).

9. Fiske, C. H., and SubbaRow, Y. J.: The colorimetric determination of phosphorus. J. Biol. Chem., 66: 375 (1925).

10. Gugler, E., Pallavicini, J. D., Swerdlow, H., and di Sant'AGNESE, P. A.: The role of calcium in submaxillary saliva of patients with cystic fibrosis. J. Pediat., 71: 585 (1967).

Il. Gugler, E., Pallavicini, J. C., Swerdlow, H., Zipkin, I., and DI SANT'AgNese, P. A.: Immunologic studies of submaxillary saliva from patients with cystic fibrosis and from normal children. J. Pediat., 73: 548 (1968).

12. HAX, D. I.: The adsorption of salivary proteins by hydroxylapatite and enamel. Arch. Oral Biol., 12: 937 (1967).

13. Kunitz, M.: Crystalline ribonuclease. J. Gen. Physiol., 24: 15 (1940).

14. Lowry, O. H., Rosebrough, N. J., Farr, A. L., and Randall, R. J.: Protein measurement with the Folin phenol reagent. J. Biol. Chem., 193: 265 (1951).

15. Mandel, I., Eriv, A., Kutscher, A., Denning, C., Thompson, R. H., Kessler, W., and Zegarelli, E.: Calcium and phosphorus levels in submaxillary saliva. Clin. Pediat., 8: 161 (1969).

16. Marmar, J., Barbero, G. J., and Stbinga, M. S.: The pattern of parotid gland secretion in cystic fibrosis of the pancreas. Gastroenterology, 50: 551 (1966). 
17. Mayo, J. W., and Carlson, D. M.: Protein composition of human submandibular secretions. Arch. Biochem. Biophys. (in press).

18. MeCKeL, A. H.: The formation and properties of organic films on teeth. Arch. Oral Biol., 10: 585 (1965).

19. McKenzie, H. A.: Milk proteins. Advan. Protein Chem., 22: 55 (1967).

20. Osserman, E. F., and Lawlor, D. P.: Serum and urinary lysozyme (muramidase) in monocytic and monomyelocytic leukemia. J. Exp. Med., 124: 921 (1966).

21. Pallavicini, J. C., and Gugler, E.: Preparative discontinuous polyacrylamide gel electrophoresis for immunological and chemical investigations of proteins. Protides Biol. Fluids Proc. Colloq. Bruges, 15: 541 (1967).

22. Perlmann, G. E.: The nature of phosphorus linkages in phosphoproteins. Advan. Protein Chem., 10: I (1955).

23. Reisfeld, R. A., Lewis, U. J., and Williams, D. E.: Disk electrophoresis of basic proteins and peptides on polyacrylamide gels. Nature, 195: 281 (1962).

24. SCHNEYER, L. H.: Collection of separate submaxillary and sublingual salivas in man. J. Dent. Res., 33: 683 (1954).

25. Shannon, I. L., and Prigmore, J. R.: The effect of flow rate on parotid fluid composition. (United States Air Force School of Aviation Medicine Report 60-77, 1960).

26. Sprro, R. G.: Glycoproteins: Their biochemistry, biology, and role in human disease. New Engl. J. Med., 281: 991 (1969).

27. SVENNERHOLM, L.: Quantitative estimation of sialic acids. II. A colorimetric resorcinol-hydrochloric acid method. Biochim. Biophys. Acta, 24: 604 (1957).

28. Van Loon, E. J., Likins, M. R., and Seger, A. J.: Photometric method for blood amylase by use of starch-iodine color. Amer. J. Clin. Pathol., 22: 1134 (1952).

29. WAdsworth, C.: A microplate technique employing an agar gel chamber compared with other micro- and macroplate techniques for immune diffusion. Int. Arch. Allergy Appl. Immunol., 21: 131 (1962).

30. WEBER, K., AND OsBoRN, M.: The reliability of molecular weight determinations by dodecyl sulfate-polyacrylamide gel electrophoresis. J. Biol. Chem., 175: 595 (1969).

31. Wharton, K. L., and Blomfield, J.: Hydroxylapatite in the pathogenesis of cystic fibrosis. Brit. Med. J., 3: 683 (1971).

32. Wotman, S., Mercadante, J., Mandel, I. D., Goldman, R. S., AND Denning, C.: The occurrence of calculus in normal children, children with cystic fibrosis, and children with asthma. J. Periodontal., 44: 278 (1973).

33. WrigleY, C.: Gel electrofocusing-A technique for analyzing multiple protein samples by isoelectric focusing. Science Tools, Vol. 15, No. 2 (LKB Instrument Co., 1968).

34. Hog stomach pepsin-PM (three times crystallized), TrypsinTRL (two times crystallized), horse heart myoglobin (two times crystallized), egg-white lysozyme, horse heart cytochrome $c$, bovine pancreas $\alpha$-chymotrypsin, and RNase A were obtained from Schwartz-Mann and were used without further purification.

35. Ultrapure urea and guanidine hydrochloride, Schwartz-Mann, Orangeburg, N.Y.

36. The authors wish to acknowledge the assistance and support of Dr. P. A. di Sant'Agnese, and helpful suggestions concerning preparation of the manuscript by Dr. J. Mayo and Dr. P. Farrell.

37. Present address: Department of Pediatrics, University of Berne, Berne, Switzerland.

38. This research was supported in part by Grants nos. HL 14844 and AM 08305 from The United States Public Health Service, and from The Health Fund of Cleveland.

39. Requests for reprints should be addressed to: THomas $\mathbf{F}$. BoAT, M.D., Rainbow Babies and Childrens Hospital, 2103 Adelbert Rd., Cleveland, Ohio 44106.

40. Accepted for publication December 11, 1973. 